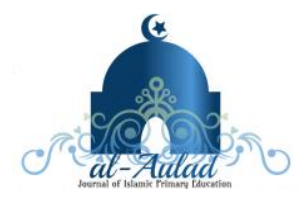

\title{
MENINGKATKAN SIKAP SOSIAL MELALUI PENERAPAN MODEL PEMBELAJARAN VALUE CLARIFICATION TECHNIQUE
}

\author{
Siti Nurasiah ${ }^{1}$ \\ ${ }^{\prime}$ MI Nurul Yakin, Cileunyi, Kabupaten Bandung, Indonesia \\ stnurasiah96@gmail.com
}

Naskah diterima: 1 Desember, 2018, direvisi: 29 Januari, 2019, diterbitkan: 31 Maret, 2019

\begin{abstract}
This study aims to determine the social attitudes of students before and after using the value clarification technique (VCT) learning model. The research method used is Classroom Action Research which consists of planning, implementing, observing, and reflecting which lasts for two cycles, with the subject of class V MI Nurul Yakin, amounting to 17 students. Before using the VCT learning model, the average percentage of students' social attitudes reached $47 \%$ (less). After using the VCT learning model the average percentage of students' social attitudes in the first cycle reached 58\% (less), while in cycle 2 the average percentage of students' social attitudes reached $78 \%$ (good). There were changes in the students' social attitudes in the learning process by applying the VCT learning model to the subject matter of the Akhah Akhlak the subject fosters harmony with neighbors and society.
\end{abstract}

Keywords: Akidah Akhlak, Social Attitudes, VCT Learning Model

\begin{abstract}
ABSTRAK
Penelitian ini bertujuan untuk mengetahui sikap sosial peserta didik sebelum dan sesudah menggunakan model pembelajaran value clarification technique (VCT). Metode penelitian yang digunakan adalah Penelitian Tindakan Kelas yang terdiri dari perencanaan, pelaksanaan, pengamatan, dan refleksi yang berlangsung selama dua siklus, dengan subjek peserta didik kelas $\mathrm{V}$ MI Nurul Yakin yang berjumlah 17 peserta didik. Sebelum menggunakan model pembelajaran VCT rata-rata persentase sikap sosial peserta didik mencapai47\% (kurang sekali). Setelah menggunakan model pembelajaran VCT rata-rata persentase sikap sosial peserta didik pada siklus I mencapai 58\% (kurang), sedangkan pada siklus 2 rata-rata persentase kemampuan sikap sosial peserta didik mencapai 78\% (baik).Terdapat perubahan sikap sosial peserta didik pada proses pembelajaran dengan menerapkan model pembelajaran VCT pada mata pelajaran Akidah Akhlak pokok bahasan membina keharmonisan dengan tetangga dan masyarakat.
\end{abstract}

Kata Kunci: Akidah Akhlak, Model pembelajaran VCT, Sikap Sosial.

\section{PENDAHULUAN}

Negara dikatakan maju apabila memiliki sumber daya manusia yang berkualitas. Salah satu usaha untuk membentuk sumber daya manusia yang berkualitas adalah pendidikan. Menurut Langeveld pendidikan adalah upaya pemberian bantuan secara sadar dan sengaja kepada seseorang yang belum dewasa dalam perkembangannya menuju ke arah kedewasaanya sehingga ia dapat hidup secara mandiri dan bertanggung jawab susila terhadap tindakannya atas pilihannya sendiri ( Aisyah, 2013). Sekolah merupakan salah satu lembaga pendidikan yang bertanggung jawab untuk mengembangkan potensi yang dimiliki oleh peserta didik baik dari segi pengetahuan, sikap dan keterampilan. Belajar adalah proses untuk mengembangkan potensi yang dimiliki oleh peserta didik.

Setiap proses pembelajaran yang dilakukan oleh pendidik dilaksanakan berdasarkan tujuan pendidikan. Tujuan pendidikan yang ingin dicapai dalam setiap pembelajaran dapat 
dikategorikan menjadi tiga bidang yaitu, bidang kognitif (penguasaan intelektual), bidang afektif (berhubungan dengan sikap dan nilai) serta bidang psikomotor (kemampuan atau keterampilan bertindak atau berperilaku) (Sudjana, 1995). Keberhasilan peserta didik dalam proses pembelajaran dapat terlihat dari adanya perubahan ke arah yang lebih baik lagi baik secara kognitif, afektif dan psikomotorik. Namun fakta dilapangan belum menunjukkan hasil yang diharapkan. Pendidikan masih berorientasi pada aspek kognitif dan kurang memperhatikan aspek afektif dan psikomotorik sehingga peserta didik memiliki kemampuan kognitif peserta didik yang cukup tinggi tidak diimbangi dengan kemampuan afektifnya sehingga peserta didik memiliki sikap sosial yang kurang. Hal ini tampak dari pengamatan yang dilakukan peneliti pada kegiatan pembelajaran.

Sejalan dengan permasalahan tersebut, perlu adanya penerapan pembelajaran yang baik melalui pengintegrasian nilai-nilai karakter dalam proses pembelajaran Akidah Akhlak. Untuk itu perlu dikembangkan model pembelajaran berbasis karakter melalui klarifikasi nilai-nilai karakter atau model pembelajaran value clarification technique (VCT) yang melibatkan partisipasi aktif peserta didik dengan permasalahan yang konkrit dan bermakna. Keberhasilan penggunaan model pembelajaran VCT ini telah dibuktikan oleh penelitian yang dilakukan N. I. P. Eka Agustini, Ndra Tanggu Renda dan I Nyoman Murda (2015) yang mengungkapkan bahwa model pembelajaran VCT dapat meningkatkan hasil belajar siswa pada ranah afektif. Selain itu, Agustina Tri Wijayanti (2013) melakukan penelitian yang menunjukkan bahwa pembelajaran dengan menerapkan model pembelajaran VCT dapat memunculkan perilaku positif siswa seperti aspek nilai religius dan taat beribadah, toleransi terhadap sesama, disiplin, kepedulian terhadap teman, bermusyawarah dan tanggung jawab dalam menyelesaikan tugas tepat waktu baik individu maupun kelompok.

Pengembangan aspek afektif sangat penting pada jenjang sekolah dasar. Menurut Piaget karakteristik usia peserta didik sekolah dasar berada pada tahap operasi konkret dalam berpikir berada pada usia 7-12 tahun, pada tahap ini anak memiliki pemikiran yang logis terhadap objek konkret yang ada disekitarnya, berkurangnya rasa ego dalam dirinya, dan mulai bersikap sosial dengan lingkungannya (Rufaida, 2013). Sikap dalam perkembangannya banyak dipengaruhi oleh lingkungan, norma-norma atau kelompok. Hal ini mengakibatkan perbedaan sikap antara individu yang satu dengan yang lainnya karena perbedaan pengaruh atau lingkungan yang diterima. Sikap tidak akan terbentuk tanpa interaksi manusia terhadap suatu objek tertentu. Salah satu ciri sikap adalah sikap tidak menetap, hal ini menunjukkan sikap dapat dibentuk dan berkembang sesuai dengan apa yang dialaminya.

Pendidik merupakan salah satu faktor yang berperan penting dalam pembelajaran. Pendidik dituntut untuk dapat menerapkan model pembelajaran yang sesuai dengan tujuan pembelajaran yang akan dicapai sehingga pembelajaran dapat optimal. Pengalaman yang didapatkan peserta didik pada saat proses pembelajaran tentu akan membentuk sikap peserta didik terhadap suatu objek, baik itu sikap terhadap dirinya, orang lain, benda dan lain sebagainya. Salah satu usaha yang dapat dilakukan oleh pendidik dalam mengembangkan potensi yang dimiliki oleh peserta didik adalah pemilihan model pembelajaran yang digunakan. Penggunaan model pembelajaran harus disesuaikan dengan tujuan yang ingin dicapai atau aspek apa yang ingin dikembangkan.

Salah satu model pembelajaran yang sesuai untuk mengembangkan aspek sikap adalah model pembelajaran value clarification technique (VCT). VCT adalah model pengajaran untuk membantu peserta didik dalam menemukan dan menentukan suatu nilai yang dianggap baik dalam menghadapi suatu persoalan atau dilema melalui proses menganalisis 
nilai yang sudah ada sebelumnya dan tertanam dalam diri peserta didik. Salah satu karakter VCT sebagai suatu model dalam strategi pembelajaran sikap adalah proses penanaman nilai dilakukan melalui proses analisis nilai yang sudah ada sebelumnya dalam diri siswa kemudian menyesuaikannya dengan nilai-nilai baru yang henak ditanamkan (Wiratama, 2012).

Menurut Jarolimek dalam model pembelajaran VCT terdapat tujuh tahapan yang dibagi ke dalam tiga tingkat, yaitu, tingkatan yang pertama, kebebasan memilih yang terdiri dari tiga tahap yaitu memilih secara bebas, memilih dari beberapa alternatif, memilih setelah dilakukan analisis peertimbang konsekuensi yang akan timbul sebagai akibat pilihannya.tingkatan yang kedua, yaitu menghargaiyang terdiri dari dua tahap, yaitu, adanya perasaan senang dan bangga dengan nilai yang menjadi pilihannya, menegaskan nilai yang sudah menjadi bagian integral dalam dirinya di depan umum. Tingkatan yang ketiga, berbuat yang terdiri dari dua tahapan yaitu, kemauan dan kemampuan untuk mencoba melaksanakannya dan mengulangi perilaku sesuai dengan nilai pilihannya (Setiana, 2012).

Menurut Chaplin social attitudes (sikap sosial) yaitu 1) satu presdisposisi atau kecenderungan untuk bertingkah laku terhadap orang lain dengan cara tertentu; 2) satu pendapat umum; dan 3) satu sikap yang mengarah kepada tujuan-tujuan sosial, sebagai lawan dari sikap yang mengarah pada tujuan-tujuan pribadi (Rufaida, 2013). Seseorang memiliki sikap sosial apabila ia memiliki cara tertentu terhadap orang lain dalam bertindak dan mementingkan tujuan-tujuan sosial daripada tujuan pribadi dalam kehidupan masyarakat.

Sikap sosial terbentuk dari pengalaman individu ketika melakukan interaksi sosial. Gerungan (2010) menyatakan bahwa dalam pembentukkan dan perubahan attitude itu terdapat faktor-faktor internal dan eksternal pribadi individu tang memegang peranannya. Faktor internal berupa selektivitasnya sendiri, daya pilihnya sendiri atau minat perhatiannya untuk menerima dan mengolah pengaruh-pengaruh yang datang dari luar dirinya itu. Sedangkan faktor eksternal berupa interaksi antara manusia denga objek tertentu. Interaksi sosial di dalam kelompok maupun di luar kelompok dapat mengubah attitude atau membentuk attitude yang baru.

Sikap dalam perkembangannya banyak dipengaruhi oleh lingkungan, norma-norma atau kelompok. Hal ini mengakibatkan perbedaan sikap antara individu yang satu dengan yang lainnya karena perbedaan pengaruh atau lingkungan yang diterima. Sikap tidak akan terbentuk tanpa interaksi manusia terhadap suatu objek tertentu. Salah satu ciri sikap adalah sikap tidak menetap, hal ini menunjukkan sikap dapat dibentuk dan berkembang sesuai dengan apa yang dialaminya.

Menurut Soetjipto dan Sjafioedin seseorang memiliki sikap sosial terlihat dari adanya kerja sama, sikap tenggang rasa, dan solidaritas. Senada dengan pendapat Soetjipto dan Sjafioedin Nawawi menjelaskan bahwa sikap sosial seseorang dapat berupa tenggang rasa, kerja sama dan solidaritas.

a. Kerja sama, merupakan suatu kecenderungan untuk bertindak dalam suatu kegiatan yang dilakukan secara bersama-sama untuk mencapai tujuan bersama. Ciri-ciri orang yang memiliki sikap kerja sama adalah aktif dalam kegiatan gotong royong, tidak membiarkan orang lain menghadapi kesulitan sendiri, mengutamakan hidup bersama dan lain sebagainya.

b. Solidaritas, adalah kecenderungan yang dimiliki oleh seseorang untuk memperhatikan orang lain. Seseorang yang memiliki sikap solidaritas akan memerhatikan keadaan seseorang terutama yang sedang mengalami kesulitan. 
c. Tenggang Rasa, adalah suatu kecenderungan yang dimiliki seseorang untuk menjaga perasaan orang lain dalam aktivitas yang dilakukannya. Sikap tenggang rasa dapat terlihat dari adanya rasa saling menghargai perbedaan satu sama lain, bertutur kata yang baik sehingga tidak menyinggung perasaan orang dan lain sebagainya (Arifin, 2015).

Madrasah ibtidaiyah menjadikan akidah akhlak sebagai salah satu mata pelajaran yang harus dipelajari oleh peserta didik. merupakan mata pelajaran yang mengajarkan dan membimbing peserta didik untuk mampu mengetahui dan meyakini akidah Islam sehingga peserta didik memiliki akhlak yang baik sesuai dengan yang ada di Al-quran dan Sunnah. Salah satu ruang lingkup mata pelajaran akidah akhlak adalah aspek akhlak Pembiasaan akhlak karimah (mahmudah), yaitu: disiplin, hidup bersih, ramah, sopan santun, hidup sederhana, rendah hati, jujur, rajin, percaya diri, taat, rukun, tolong menolong, hormat dan patuh, amanah, tabligh, fatanah, adil, bijaksana, dermawan, optimis, qana'ah, dan tawakal.

Proses pembelajaran akidah akhlak diharapkan dapat memberikan dampak nyata terhadap akhlak peserta didik, baik secara individual maupun sosial. sehingga model pembelajaran afektif harus digunakan dan dikembangkan oleh pendidik. Untuk mengembangkan sikap, banyak model pembelajaran yang dapat dipilih dan digunakan. Setiap model pembelajaran sikap pada umumnya menghadapkan peserta didik pada situasi yang mengandung konflik atau situasi yang problematis. Melalui situasi ini diharapkan peserta didik dapat mengambil kepurusan berdasarkan nilai yang dianggapnya baik. model pembelajaran sikap diantaranya: 1) Model konsiderasi, 2) model pengembangan kognitif, 3) teknik mengklarifikasi nilai.

Sesuai dengan permasalahan yang peneliti temukan, maka dipilih salah satu model pembelajaran afektif atau sikap yaitu model pembelajaran VCT. Menurut Wijayanti (2013) teknik mengklarifikasi nilai dterapkan dalam pembelajaran maka dapat meningkatkan kemampuan peserta didik untuk: 1) memilih, memutuskan, mengkomunikasikan, mengungkapkan gagasan, keyakinan, nilai-nilai dan perasaannya, 2) berempati atau memahami perasaan orang lain dan melihat sudut pandang orang lain, 3) memecahkan masalah, 4) menyatakan sikap setuju, menolak atau menerima pendapat orang lain, 5) mempunyai pendirian dalam mengambil keputusan, menginternalisasikan, dan bertinkah laku sesuai dengan nilai yang dipilih dan diyakini.

Dengan adanya penelitian ini, yaitu penerapan model pembelajaran VCT pada kelas V MI Nurul Yakin Kecamatan Cileunyi Kabupaten Bandung pada mata pelajaran akidah akhlak untuk meningkatkan sikap sosial peserta didik diharapkan dapat memberikan kontribusi terhadap pengembangan kualitas pembelajaran akidah akhlak. Selain itu penelitian juga dapat bermanfaat bagi pendidik dalam merancang dan melaksanakan pembelajaran akidah akhlak yang bermakna dan inovatif. Diharapkan juga pendidik dapat mengembangkan model pembelajaran afektif atau sikap yang lainnya sehingga pembelajaran akidah akhlak dapat lebih bervariasi dalam rangka memperbaiki sikap maupun hasil belajar kognitif dan psikomotor peserta didik.

\section{METODOLOGI}

Metode yang digunakan dalam penelitian ini adalah Penelitian Tindakan Kelas (PTK), penelitian ini merupakan penelitian yang dilakukan oleh guru atau peneliti untuk memperbaiki proses pembelajaran dengan memberikan tindakan yang diawali dengan proses perencanaan sampai melakukan refleksi untuk melihat pengaruh tindakan yang dilakukan. Jenis data terdiri dari data kuantitatif dan kualitatif. Data kuantitatif diperoleh dari hasil lembar observasi sikap sosial peserta didik menggunakan model pembelajaran 
VCT yang diasumsikan dapat terjadi peningkatan sikap sosial peserta didik di kelas. Data kualitatif digunakan untuk mengetahui gambaran proses keterlaksanaan model pembelajaran VCT.

Penelitian ini dilaksanakan di Madrasah Ibidaiyah Nurul Yakin yang bertempat di Cileunyi Kabupaten Bandung Jawa Barat. Subjek dalam penelitian ini adalah peserta didik kelas V MI Nurul Yakin dengan jumlah 17 orang, terdiri dari sepuluh laki-laki dan tujuh perempuan. penelitian dilakasanakan melalui empat tahap, yaitu: perencanaan (planning), pelaksanaan (action), pengamatan (observation) dan refleksi (reflection). Pertama, pada tahap perencanaan pendidik merencanakan hal-hal sebagai berikut: 1) Menyusun rencana pelaksanaan pembelajaran pokok bahasan menjaga keharmonisan dengan tetanggadan masyarakat, 2) Mempersipakan sumber belajar, yaitu buku paket guru dan siswa, 3) Mempersiapkan media pembelajaran, yaitu cerita berdilema dan gambar pengandaian, 4) Menyusun lembar aktivitas pendidik, peserta didik dan sikap sosial peserta didik. Kedua, pada tahap pelaksanaan pendidik melaksanakan tindakan sesuai dengan rencana, ditahap ini pula proses pembelajaran diamati oleh seorang observer. Ketiga, tahap pengamatan dilakukan bersamaan dengan pelaksanaan tindakan. Pada tahap ini observer mengumpulkan berbagai informasi di kelas dari mulai aktivitas pendidik, peserta didik dan sikap sosial pada saat pelaksanaan tindakan dengan mengacu pada lembar observasi yang telah disusun sebelumnya. Keempat, tahap refleksi pada tahap ini pendidik dan observer melakukan evaluasi terhadap pelasanaan tindakan dan melakukan yindak lanjut untuk siklus selanjutnya.

Sumber data primer dalam penelitian ini adalah peserta didik kelas V MI Nurul Yakin Kecamatan Cileunyi Kabupaten Bandung dan guru mata pelajaran. Sumber data sekunder diperoleh dari dokumentasi seperti foto-foto kegiatan pembelajaran, RPP dan lain sebagainya.

Teknik pengumpulan data dalam penelitian ini menggunakan observasi dan dokumentasi. Observasi dilakukan untuk menghimpin data mengenai aktivitas pendidik, peserta didik dan sikap sosial peserta didik pada saat proses pembelajaran berlangsung. Dokumentasi digunakan untuk memperoleh data berupa dokumen yang berhubungan dengan penelitian, diantaranya; catatan harian peserta didik, absensi kehadiran peserta didik dan foto-foto pada saat pelaksanaan tindakan.

Analisis data yang dilakukan dalam penelitian ini Realita penerapan model pembelajaran VCT diukur menggunakan lembar observasi aktivitas peserta didik dan pendidik. Sikap sosial peserta didik diukur dengan menggunakan lembar observasi sikap sosial. Analisis data dilakukan dengan langkah-langkah sebagai berikut:

1. Menjumlah skor dari seluruh aspek yang diamati

2. Mencari skor rata-rata dari setiap indikator sikap dengan membagi jumlah skor oleh banyaknya pernyataan,

3. Mencari persentase hasil observasi dengan menggunakan rumus menurut Sudjana (2002:133) sebagai berikut:

Persentase $(\%)=\frac{\text { Skor yang diproleh }}{\text { Skor maksimal }} \times 100$ berikut:

Setelah diperoleh hasil dan persentasenya, peneliti menafsirkan ke dalam kriteria 
Tabel 1. Kriteria penilaian

\begin{tabular}{|c|c|}
\hline Tingkat penguasaan & Predikat \\
\hline $86-100 \%$ & Sangat baik \\
$76-85 \%$ & Baik \\
$60-75 \%$ & Cukup \\
$55-59 \%$ & Kurang \\
$\leq 54 \%$ & Kurang sekali \\
\hline \multicolumn{2}{|c|}{ Sumber: Purwanto, 2012 } \\
\hline
\end{tabular}

\section{HASIL DAN DISKUSI}

a. Sikap sosial peserta didik pada Pra Siklus

Berdasarkan hasil pengamatan mata pelajaran Akidah Akhlak sebelum menggunakan model pembelajaran VCT, diperoleh nilai rata-rata persentase sebesar $46,5 \%$ dari 17 peserta didik yang diamati. Peserta didik belum mampu untuk bekerja sama dalam kelompok, hasil kerja kelompok hanya dari satu orang saja, pada kegiatan pra siklus ini pendidik membagi peserta didik ke dalam kelompok kecil, dalam setiap kelompok berjumlah dua anggota. Dalam kelompok tidak terjadi diskusi, hasil kelompok hanya berasal dari satu anggota saja, sedangkan anggota yang lain memiliki aktivitas lain ada yang diam, mengobrol, dan bermain-main dengan anggota kelompok yang lain. Pada kegiatan diskusi ini pendidik membiarkan peserta didik, tidak melakukan pengarahan, sehingga kegiatan diskusi ini tidak berjalan dengan baik. Pada saat peserta didik salah menjawab pertanyaan yang diberikan oleh pendidik, peserta didik yang lain mengolokoloknya dan suasana pembelajaran menjadi gaduh. Hal ini menunjukkan bahwa sikap sosial peserta didik kurang sekali. Salah satu model pembelajaran yang dapat meningkatkan sikap sosial peserta didik adalah model pembelajaran VCT sesuai dengan pendapat Sara (2016) yang menyatakan bahwa model pembelajaran VCT efektif dalam mengembangkan sikap siswa.

b. Aktivitas pendidik dan peserta didik pada siklus I

Aktivitas pendidik selama pembelajaran menggunakan model pembelajaran VCT pada siklus I termasuk kedalam kriteria baik dengan peroleh nilai sebesar 80,4\% dan indikator yang belum tercapai sebesar $19,6 \%$. Aktivitas peserta didik selama mengikuti kegiatan pembelajaran pada siklus I termasuk kedalam kategori cukup dengan perolehan nilai sebesar $65,25 \%$ indikator yang belum tercapai sebesar 34,75\%. Aspek ketercapaian yang belum maksimal pada siklus I ini dikarenakan kurangnya aktivitas belajar peserta didik dengan menggunakan model pembelajaran yang diterapkan oleh pendidik dan penataan tempat duduk yang belum efektif. Selain itu, peserta didik masih belum dapat beradaptasi dengan model pembelajaran VCT yang menekankan pada sisi afektif. Pendidik juga belum menyampaikan tahap-tahap model pembelajaran VCT secara sempurna sehingga pembelajaran belum maksimal dan harus diperbaiki pada siklus II agar seluruh tahapan dapat tersampaikan secara maksimal.

c. Aktivitas pendidik dan peserta didik pada siklus II

Aktivitas pendidik selama pembelajaran menggunakan model pembelajaran VCT pada siklus II termasuk kedalam kriteria sangat baik dengan perolehan nilai mencapai 91,85\%. Hal ini menunjukkan bahwa ketercapaian aktivitas pendidik pada siklus II sudah mencapai peningkatan yang tinggi. Aktivitas peserta didik selama mengikuti kegiatan pembelajaran pada siklus II termasuk kedalam kategori baik dengan perolehan nilai sebesar $82 \%$. Aspek ketercapaian yang masih belum tercapai dikarenakan peserta didik masih kurang maksimal dalam mengikuti pembelajaran dengan model pembelajaran VCT yang setiap pembelajarannya menggunakan teknik yang berbeda-beda sehingga mengharuskan peserta didik untuk terus beradaptasi. 
Tabel 1. Peningkatan Ativitas Pendidik dan Peserta didik

\begin{tabular}{|c|c|c|c|c|}
\hline No & Siklus & Pendidik/peserta didik & Rata-rata & Kriteria \\
\hline 1 & I & Pendidik & 80,4 & Baik \\
\hline 2 & & Peserta didik & 65,25 & Cukup \\
\hline 3 & II & Pendidik & 91,85 & Sangat Baik \\
\hline 4 & & Peserta didik & 82 & Baik \\
\hline
\end{tabular}

Berdasarkan tabel 1 aktivitas pendidik dan peserta didik mengalami peningkatan pada setiap siklusnya. Aktivitas pendidik mengalami peningkatan sebesar $11,45 \%$. Sedangkan aktivitas peserta didik mengalami peningkatan sebesar $16,75 \%$.

d. Sikap sosial peserta didik pada siklus I

Sikap sosial peserta didik pada siklus I diperoleh hasil persentase sebesar 58,5\% dapat dikatakan bahwa sikap sosial peserta didik dalam kategori kurang. Pada indikator kerja sama diperoleh hasil persentase sebesar 63,2\%. Pada indikator solidaritas kepada teman diperoleh hasil persentase sebesar 56,85\%. Dan pada indikator tenggang rasa dalam kelompok diperoleh hasil persentase sebesar 55,85\%. Hasil ini menunjukkan bahwa penelitian pada siklus I harus dilanjutkan ke siklus II dan diadakan perbaikan proses pembelajaran oleh pendidik pada siklus II.

e. Sikap sosial peserta didik pada siklus II

Sikap sosial peserta didik pada siklus II mengalami peningkatan hasil persentase diperoleh sebesar 78,6\% hasil ini terdapat dalam kategori baik. Pada indikator kerja sama diperoleh hasil persentase sebesar 84,55\%. Pada indikator solidaritas kepada teman diperoleh hasil persentase sebesar 79,4\%. Dan pada indikator tenggang rasa dalam kelompok diperoleh hasil persentase sebesar $72 \%$.

Tabel 2. Peningkatan Sikap Sosial Peserta Didik

\begin{tabular}{|c|c|c|c|}
\hline No & Siklus & Persentase & Keterangan \\
\hline 1 & Pra Siklus & 46,5 & Kurang Sekali \\
\hline 2 & Siklus I & 58,5 & Cukup \\
\hline 3 & Siklus II & 78,6 & Baik \\
\hline
\end{tabular}

Tabel 2 menunjukkan bahwa sikap sosial peserta didik pada setiap tahapnya sikap sosial peserta didik mengalami peningkatan. Pada tahap pra siklus ke siklus I terjadi peningkatan sebesar 12\%. Pada siklus I ke siklus II terjadi peingkatan sebesar 20,1\%. Peningkatan ini dapat dilihat pada grafik di bawah ini:

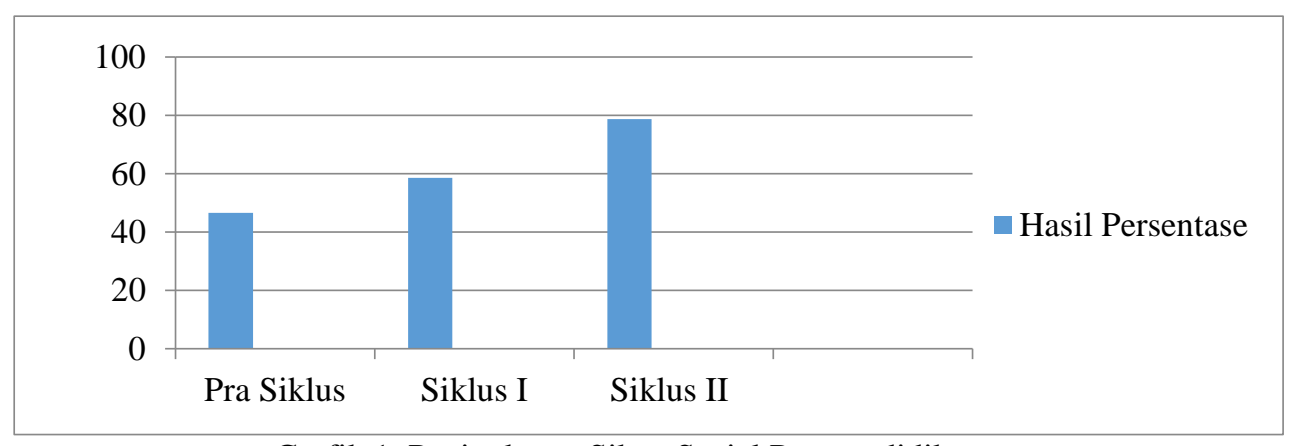

Grafik 1. Peningkatan Sikap Sosial Peserta didik 
Berdasarkan analisis dari hasil penelitian tersebut, dapat disimpulkan bahwa melalui model pembelajaran VCT, proses pembelajaran menjadi lebih baik dan sikap sosial peserta didik kelas V MI Nurul Yakin Kecamatan Cileunyi Kabupaten Bandung pokok bahasan membina keharmonisan dengan tetangga dan masyarakat dapat ditingkatkan. Peningkatan dihasilkan setelah menggunakan model pembelajaran VCT. Hal ini sesuai dengan pendapat Djahiri (Jaya, 2010) bahwa dengan model pembelajaran VCT ini peserta didik dibina kesadaran emosionalnya nilainya melalui cara yang kritis, pengklarifikasian dan menguji kebenaran kebaikan, keadilan dan kelayakan dan keteptannya. Sikap sosial dapat ditingkatkan karena pada proses pembelajarannya peserta didik dihadapkan pada cerita berdilema nilai/moral yang meminta peserta didik untuk menentukan pilihannya berdasarkan pertimbangan akibat yang akan ditimbulkan dari pilihan tersebut. Sehingga hipotesis penelitian tindakan yang diajukan peneliti dapat diterima bahwa dengan menggunakan model pembelajaran VCT dapat meningkatkan sikap sosial peserta didik pada mata pelajaran Akidah Akhlak pokok bahasan menjaga keharmonisan dengan tetangga dan masyarakat.

\section{KESIMPULAN}

Sikap sosial peserta didik kelas V MI Nurul Yakin sebelum menggunakan model pembelajaran VCT memperoleh nilai persentase $47 \%$ hasil ini menunjukkan sikap sosial peserta didik berada pada kategori kurang sekali. Hasil observasi aktivitas pendidik pada siklus I memperoleh nilai persentase sebesar $80,4 \%$ termasuk kedalam kriteria baik. aktivitas peserta didik pada siklus I memperoleh nilai persentase sebesar $62,25 \%$ termasuk pada kategori cukup. Hasil observasi sikap sosial peserta didik pada siklus I memperoleh nilai sebesar 58\%. Hasil observasi aktivitas pendidik pada siklus II memperoleh nilai persentase sebesar 91, 85\% termasuk kedalam kategori sangat baik. Hasil observasi sikap sosial peserta didik pada siklus II memperoleh nilai sebesar $82 \%$ termasuk kedalam kategori baik. hasil observasi sikap sosial pada siklus II memeperoleh nilai 78,6\% termasuk kedalam kategori baik. hasil penelitian menunjukkan bahwa ranah afektif atau sikap khususnya sikap sosial dapat dijadikan sebagai bahan untuk penelitian. Karena hasil belajar tidak hanya aspek pengetahuan tetapi ada aspek sikap dan keterampilan yang penting untuk diteliti. Penggunaan model pembelajaran afektif juga patut mendapatkan perhatian karena model pembelajaran afektif dapat memberikan pengalaman yang berbeda kepada peserta didik karena jarang digunakan pada saat proses pembelajaran. Pemilihan aspek sikap dan model pembelajaran afektif dapat dijadikan pilihan bagi mahasiswa pendidikan guru madrasah ibtidaiyah yang akan melakukan penelitian sehingga hasil penelitian akan lebih variatif.

\section{DAFTAR PUSTAKA}

Agustina Tri Wijayanti. 2013. Implementasi Pendekatan Value Clarification Technique (VCT) dalam Pembelajaran IPS di Sekolah Dasar. Retrieved from https://journal.uny.ac.id/index.php/sosia/article/view/5343

Bambang Syamsul Arifin. 2015. Psikologi Sosial. Bandung: CV Pustaka Setia

Elvita Jaya, 2010. Penerapan teknik VCT (Value Clarification Technique model cerita untuk meningkatkan hasil belajarpendidikan agama islam pada materi akhlak terpuji di sekolah dasar negeri 041 tampan kecamatan tampan kota pekanbaru. Retrieved from http://repository.uin-suska.ac.id/23/1/2010_201199.pdf 
Gd. Arya Wiratama, dkk.2012. Pengaruh Model Pembelajaran VCT Berbantuan Media Cerita Bergambar Terhadap Hasil Belajar Ranah Afektif Siswa Mata Pelajaran PKN Kelas IV SD. . E-Journal PGSD Universitas Pendidikan Ganesha Jurusan PGSD.

Gustin Indra Setiana. 2012. Penerapan Model Pembelajaran Value Clarification Technique Permainan untuk Meningkatkan Hasil Belajar Pkn pada Siswa Kelas II SD Negeri Kemandungan 3 Kota Tegal. Retrieved from https://lib.unnes.ac.id/17956/

M. Ngalim Purwanto. 2017. Prinsip-prinsip dan Teknik Evaluasi Pengajaran. Bandung: PT Remaja Rosdakarya

Nana, Sudjana. 1995. Dasar-dasar Proses Belajar Mengajar. Bandung: Sinar Baru Algesindo

N.L.P.Eka Agustini, dkk. (2015). Pengaruh Model Pembelajaran VCT terhadap Hasil belajar Ranah Afektif Mata Pelajaran PKn Siswa. E-Journal PGSD Universitas Pendidikan Ganesha Jurusan PGSD.

Sara Puspitaning Tyas. (2016). Keefektifan Model Pembelajaran Value Clarification Technique dalam Mengembangkan Sikap Siswa. Retrieved from http://ejournal.uksw.edu/satyawidya/article/view/724

Siska Difki Rufaida. 2013. Pengembangan Sikap Sosial Siswa Menggunakan Pendekatan Pakem pada Pembelajaran IPS Kelas VB SD Negeri Mangiran, Kecamatan Srandakan Kabupaten Bantul.Skripsi: tidak diterbitkan

W.A. Gerungan. 2010. Psikologi Sosial. Bandung: Refika Aditama 